\title{
Media Monopoli Sains (MONOIN) Untuk Pembelajaran IPA Pada Materi Semester I Kelas IV
}

\section{Mohammad Ariya ${ }^{1 *}$, Novanita Whindi Arini2}

${ }^{1,2}$ Jurusan Pendidikan Guru Sekolah Dasar, Universitas Muhammadiyah Prof. Dr. Hamka, Jakarta Timur, Indonesia

\section{A R T I C LE IN F O}

Article history:

Received may 09, 2021

Revised May 15, 2021

Accepted June 29, 2021

Available online July 25, 2021

Kata Kunci:

Media Pembelajaran,

Monopoli, Pembelajaran

IPA

\section{Keywords:}

Learning Media, Monopoly, Science Learning

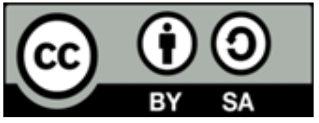

This is an open access article under the CC BY-SA license.

Copyright () 2021 by Author. Published by Universitas Pendidikan Ganesh

\begin{abstract}
A B S T R A K
Penelitian ini dilaksanakan berdasarkan hasil analisis lapangan kepada guru yang kesulitan mengembangkan media pembelajaran sehingga siswa merasa jenuh dalam proses pembelajaran dan tidak dapat memahami materi secara maksimal. Penelitian ini bertujuan mengembangkan dan menguji kelayakan media pembelajaran Monopoli Sains (MONOIN) untuk mata pembelajaran IPA semester 1 (satu) pada Kelas IV Sekolah dasar. Riset ini memakai pengembangan (R\&D). Penelitian ini menggunakan model ADDIE. Data yang dikumpulkan adalah data kualitatif dan kuantitatif dengan menggunakan metode observasi, wawancara dan angket. Subjek pada penelitian ini adalah 3 orang pakar yang terdiri dari ahli media, ahli materi dan guru, serta uji coba dilakukan pada kelompok kecil 5 siswa dan kelompok besar 10 siswa pada kelas IV untuk uji coba media. Hasil review validasi oelh ahli media didapatkan persentase sebesar $79 \%$ dikategorikan" Baik", hasil validasi ahli materi didapatkan persentase sebesar 95,2\% dikategorikan "Sangat Baik", hasil validasi pendidikan didapatkan persentase sebesar $97,3 \%$ dikategorikan "Sangat Baik", hasil respon peserta didik pada kelompok kecil didaptkan persentase sebesar $87,73 \%$ dikategorikan "sangat baik" dan kelompok besar didapatkan hasil 94,40\% dikategorikan "Sangat Baik". berdasarkan hasil perolehan data dapat disimpulkan bahwa media pembelajaran Monopoli Sains ini layak digunakan sebagai media pendidikan IPA semester I pada kelas IV sekolah dasar.
\end{abstract}

\section{A BS TRACT}

This research was conducted based on the results of field analysis to teachers who had difficulty developing learning media so that students felt bored in the learning process and could not understand the material optimally. This study aims to test the feasibility of Monopoly Science (MONOIN) learning media for science subjects in semester 1 (one) in Grade IV Elementary School. This research uses development (R\&D). This study uses the ADDIE model with 5 steps, namely: 1). Analysis, 2). Designs, 3). Developments, 4). Implementation, 5). Evaluation. The data collected is qualitative and quantitative data using the methods of observation, interviews and questionnaires. The subjects in this study were 3 experts consisting of media experts, material experts and teachers, and trials were carried out on small groups of 5 students and large groups of 10 students in class IV for media trials. The results of the validation review by media experts obtained a percentage of $79 \%$ categorized "Good", the results of material expert validation obtained a percentage of 95.2\% categorized "Very Good", the results of educational validation obtained a percentage of 97.3\% categorized "Very Good", the results The response of students in the small group was $87.73 \%$ categorized as "very good" and the large group was $94.40 \%$ categorized as "Very Good". Based on the results of data acquisition, it can be concluded that the Monopoly Science learning media is appropriate to be used as a science education medium for the first semester in the fourth grade of elementary school.

\section{PENDAHULUAN}

Abad ke-21 di tandai dengan abad globalisasi ataupun abad keterbukaan, dimana terjadi perubahan demi perubahan yang fundamental dan sangat berbeda dengan tata kehidupan dalam abad sebelumnya. Ilmu dan teknologi yang semakin maju pada abad ke-21 dikatakan abad yang menuntut mutu dalam seluruh usaha serta hasil kerja manusia, dan menutut adanya sumber energi manusia yang sangat bermutu, pada abad ini pula kurikulum memiliki perubahan sesuai dengan perkembangan zaman (Hakim, 2018; Haviz, 2016; Kusumaningrum, 2018). Hal tersebut dapat dihasilkan oleh lembaga-lembaga yang dikelola langsung secara handal sampai membuahkan hasil unggulan, seperti lembaga pendidikan atau sekolah. Di sekolah siswa dapat 
belajar dengan panduan dari para guru yang sudah berpengalaman dan ahli di bidangnya (Priansa, 2017; Wijaya et al., 2016). Dalam dunia pendidikan modern perlu adanya inovasi terbaru yang dapat menguntungkan pengajar dan pembelajaran (Masturah et al., 2018). Pembelajaran ialah usaha yang dicoba dengan terencana dalam menjadikan manusia yang tidak mengetahui sesuatu menjadi mengetahui sesuatu. Pendidikan berlangsung dimana saja dan kapan saja. Seseorang harus mendapatkan pendidikan agar memperoleh wawasan pengetahuan yang lebih, dan dengan pendidikan seseorang akan menjadi sosok manusia yang berguna (Ulfaeni, 2018). Pembelajaran yang efektif adalah sesuatu yang dapat memungkinkan siswa dapat belajar dengan mudah dan sesuai dengan tujuan pembelajaran dan sebagai hal penting bagi setiap manusia (Asyhari \& Silvia, 2016; Zaenal Fais et al., 2019). Untuk mencapai belajar yang diinginkan maka diperlukan media atau sarana pembelajaran.

Belajar adalah proses yang kompleks yang dipengaruhi oleh banyak aspek. Faktor- faktor yang mempengaruhi proses kegiatan sistem pembelajaran antara lain aspek guru, aspek siswa, fasilitas serta prasarana, dan faktor area. Sehubungan dengan aspek sarana dan prasaranan dibutuhkan media pembelajaran untuk menunjang kegiatan pembelajaran. Proses pembelajaran yang diterapkan kepada siswa akan lebih mudah tersampaikan dengan adanya bantuan media pembelajaran dan dapat meningkatkan minat belajar yang baru (Mukti \& Nurcahyo, 2017; Wahyuningtyas \& Sulasmono, 2020). Pemakaian media pembelajaran dalam proses belajar dinilai sanggup guna menolong siswa dalam menguasai materi pembelajaran. Media pembelajaran dianggap sebagai faktor yang sangat berarti dalam proses belajar. Salah satu fungsi utama dari media pembelajaran selaku pelengkap dorongan untuk memusatkan perhatian peserta didik, membantu siswa memahami materi pembelajaran, membangkitkan motivasi belajar siswa, mengaktifkan respon siswa, mempengaruhi hawa, kondisi, dan zona belajar yang ditata dan diciptakan oleh guru karena guru adalah komponen yang sangat berpengaruh dalam menentukan dan mengimplementasikan media pembelajaran untuk memberlakukan praktik pengajaran dengan teori pembelajaran (Kurniawan, 2020; Mukti \& Nurcahyo, 2017).

Berdasarkan hasil observasi serta wawancara dilapangan yang dilakukan dikelas IV SD Muhammadiyah 4 Kayu Putih ditemukan dalam proses pembelajaran di kelas IV guru hanya mengandalkan buku pelajaran atau biasa disebut buku siswa, sehingga minimnya rasa ingin tahu pada peserta didik dan sedikit peserta didik yang memahami materi dan konsep IPA. Selain itu guru memiliki permasalahan terkait dengan mengembangkan media pembelajaran untuk pembelajaran IPA yang lebih menarik dan dapat meningkatkan minat belajar dan menumbuhkan semangat belajar siswa. Selama ini pembelajaran IPA dilakukan hanya sebatas penyampaian materi saja tidak mengenalkan secara rinci konsep pembelajaran IPA dan tidak sesuai dengan karakteristik IPA. Namun mengingat permasalahan yang sering terjadi disekolah timbul dikarenakan kurangnya pemanfaatan media pembelajaran. Ada kalanya sekolah memiliki media pembelajaran namun tidak digunakan secara maksimal atau bahkan mereka belum memiliki media pembelajaran yang menunjang materi pembelajaran tertentu dan media pembelajaran merupakan salah satu faktor pendukung yang penting untuk meningkatkan kualitas pembelajaran (Kurniawan, 2020; Rahman et al., 2017). Media pembelajaran sangat dibutuhkan untuk membantu proses pembelajaran yang paling utama terkhusus mata pelajaran Ilmu Pengetahuan Alam (IPA), karena peserta didik sulit menguasai materi yang di informasikan, dimana mereka tidak bisa membayangkan teori pendidikan. Penggunaan media saat pembelajaran IPA dapat membantu memberi gambaran secara kongkrit. Ruang lingkup materi pembelajaran IPA sekolah dasar bertujuan untuk mengenal, merespon, dan mengapresiasi IPTEK, serta menanamkan pemikiran serta sikap ilmiah yang kritis, kreatif, serta mandiri (Wulandari et al., 2016). Dengan adanya permasalahn tersebut maka media pembelajaran perlu di buat untuk membantu siswa dalam proses pembelajaran. Media pembelajaran merupakan unsur yang sangat penting dalam pembelajaran yang fungsi utamanya sebagai alat untuk membantu guru dalam pembelajaran dan segala sesuatu yang dapat digunakan untuk mengirim semua pesan dari guru (Mukti \& Nurcahyo, 2017; Wicaksono et al., 2020). Media Pembelajaran yang sesuai untuk memudahkan proses belajar siswa adalah media pendidikan interaktif salah satunya dengan menggunakan permainan, permainan yang dapat digunakan salah satunya adalah permainan monopoli. Permainan monopoli ini sangat disenangi anak-anak ataupun orang dewasa (Ega Rima Wati, 2016). Sehingga dirasa sangat tepat bila mengkombinasikan permainan monopoli dan materi pembelajaran sehingga siswa dapat belajar dengan menyenangkan serta media pembelajaran harus mempunyai tampilan menarik dengan gambar benda yang konkrit, bagus serta menarik (Ulfaeni, 2018; Zaenal Fais et al., 2019). Pemanfaatan media pembelajaran harus disesuaikan dengan konteks materi pembelajaran yang akan dilaksanakan sehingga prinsip pemanfaatan perlu dikaitkan dengan kebutuhan dan karakteristik siswa maupun materi. Kegiatan mengajar dikelas akan efektif jika guru memanfaatkan media pembelajaran untuk menanamkan konsep kepada siswa. Digunakannya media pembelajaran permainan monopoli sebab permaianan ini adalah permainan yang dikenal cara bermainnya oleh siswa, sehingga dapat mempermudah penerapannya didalam kelas (M.Ramli, 2017), permainan monopoli merupakan salah satu jenis permainan papan yang bertujun mengumpulkan kekayaan dan menguasai komplek-komplek pada papan permainan dan juga dapat melatih siswa untuk mengatur keuangan (Deviana \& Prihatnani, 2018; Gumilang, 2019) Media pembelajaran monopoli yang dikembangkan ini nantinya bisa digunakan selama 1 Semester, karena mencakup semua materi yang ada di semester 1 kelas IV. Media Monopoli Sains (MONOIN) dibuat untuk membantu guru dalam menyampaikan materi terhadap siswa agar siswa mampu menguasai modul IPA dengan baik sehingga siswa dapat mencapai 
tujuan pembelajarannyaa (Siskawati maya, pargiti, 2016). Penggunaan media pembelajaran sangat dibutuhkan pada pembelajaran IPA karena diperlukan adanya usaha yang lebih ditingkatkan dalam proses pembelajaran IPA sehingga mutu pembelajaran yang terlaksana dapat mencapai tujuan dengan maksimal.

Pembelajaran IPA merupakan suatu hal yang penting untuk siswa dikarenakan pembelajaran IPA yang terdapat disekolah dapat dijadikan sebagai fasilitas untuk menguasai dan memahami perkembangan teknologi sesuai dengan pekembangan zaman. Tetapi pada kenyataannya pembelajaran IPA saat ini perlu adanya usaha yang lebih maksimal karena untuk mecamapai tujuan pembelajaran IPA tersendiri dan tidak keluar dari hakikat IPA. IPA adalah ilmu yang dirancang untuk memungkinkan siswa mempelajari pengetahuan, ide serta konsep dari pengalaman lewat serangkaian proses ilmiah. Ruang lingkup materi penelitian meliputi dua aspek yaitu karya ilmiah dan pemahaman konsep tua yang selaras dengan Perdiknas No. Tujuan hari ke-22 tahun 2006 yaitu untuk meningkatkan pengetahuan serta uraian konsep-konsep ilmiah yang hendak sangat berguna serta bisa diterapkan dikehidupan nyata (Suryani, 2016). Untuk memudahkan mengembangkan pengetahuannya siswa memerlukan alat yang memudahkan dirinya untuk belajar yaitu menggunakan media pembelajaran serta untuk mencapai hakikat sains secara utuh membutuhkan upaya dan kompetensi guru untuk memuat aspek hakikat IPA (Hidayah et al., 2018; siskawati maya, pargiti, 2016). Salah satu tujuan pembelajaran IPA akan berhasil apabila guru melaksanakan proses pembelajaran dengan menggunakan media pembelajaran yang mampu menumbuhkan rasa ingin tahu pada siswa (Ardhani et al., 2021). Tidak hanya itu guru dituntut untuk memberikan pengalaman langsung sehingga dapat menolong siswa untuk mendapatkan pemahaman yang lebih mendalam tentang alam. Untuk mencapai hal tersebut maka guru membutuhkan sebuah alat bantu beruba media pembelajaran.

Dalam penggunaan media pembelajaran sebagai penunjang proses pembelajaran mampu meningkatkan sikap yang tinggi terhadap sains (Zulirfan et al., 2018). Media pembelajaran alternatif IPA mampu memenuhi kriteria validitas penilaian yang tergolong dalam kriteria sangat valid, kepraktisan kelayakan pembelajaran baik, serta efektivitas peningkatan kemampuan berpikir kritis siswa secara statistik pada kriteria tinggi (Wahyuni et al., 2020). Dalam pengembangan media pembelajaran IPA pada uji keefektifan bahan ajar yang dikembangkan mampu menunjukkan perbedaan antara kelas yang diujikan terhadap kemampuan berpikir tingkat tinggi dan kemampuan penalaran ilmiah siswa, yang menghasilkan media pembelajaran IPA efektif dalam meningkatkan kemampuan penalaran ilmiah dan berpikir tingkat tinggi siswa (Fitriyati et al., 2017). Selain itu media pembelajaran juga efektif untuk meningkatkan motivasi belajar dan kemampuan berpikir kritis peserta didik pada pembelajaran yang diberikan (Nurlaela, 2017). Hasil penelitian lain juga menunjukkan bahwa media pembelajaran IPA menghasilkan kategori sangat baik selain itu keefektifan penggunaan media pembelajaran IPA juga dalam kategori sangat baik sehingga penggunaan media pembelajaran sangat cocok digunakan untuk menunjang pembelajaran IPA (Monita \& Ikhsan, 2020).

Berdasarkan pandangan di atas bahwa pengembangan media pembelajaran monopoli sains sangat berpengaruh positif serta dibutuhkan dalam proses kegiatan pembelajaran IPA karena dapat meningkatkan motivasi peserta didik dalam belajar dan menggunakan media pembelejaran monopoli lebih efektif karena dapat menjadikan siswa lebih aktif dalam proses pembelajaran (Nomleni \& Manu, 2018; Wardhana \& Alawiyah, 2017). Penelitian ini didukung oleh beberapa hasil penelitian terdahulu tentang penggunaan media pembelajaran monopoli, diantaranya menunjukan bahwa pengembangan monopoli energi (Monorgi) dapat menumbuhkan kemampuan pemahaman konsep IPA dan membantu khususnya siswa untuk memahami pengetahuan IPA dalam memecahkan masalah dan penerapan dalam kehidupan sehari-hari (Arshad et al., 2021; Ulfaeni, 2018). Kemudian pada penelitian (Risma et al., 2019) menyatakan bahwa media pembelajaran monopoli pada tema ekosistem dapat meningkatkan semangat belajar peserta didik dan dapat membantu dalam pemahaman materi pada peserta didik. Dan hasil penelitian menunjukkan bahwa pengembangan media monopoli dapat meningkatkan kemampuan pemahaman konsep IPA peserta didik serta meningkatkan motivasi siswa dan pada penelitian. Berdasarkan masalah tersebut maka tujuan dalam penelitian ini adalah mengembangkan media pembelajaran monopoli sains pada pembelajaran IPA semester 1 kelas IV sekolah dasar.

\section{METODE}

Penelitian ini merupakan penelitian pengembangan, dengan menggunakan model pengembangan ADDIE yang dibesarkan oleh Reiser dan Mollenda untuk mengetahui layak atau tidak produk yang dikembangkan, yaitu: 1). Analysis, 2). Design, 3). Development, 4). Implementation, 5). Evaluation.. adapun bagan penelitian ini dapat dilihat pada Gambar 1. Penelitian ini dilakukan di SD Muhammadiyah 41 Kayu Putih. Subjek uji coba penelitan ini dilakukan oleh ahli materi 1 orang, ahli media 1 orang dan 1 orang guru. Setelah media dinilai oleh pakar validasi kemudian media diuji cobakan ke kelompok kecil yaitu 5 siswa dan diujicobakan ke kelompok besar yaitu 10 siswa dengan karakteristik siswa yang berbeda. Pengumpulan data pada penelitian ini menggunakan metode observasi, wawancara dan angket. Observasi dilaksankan ketika proses analisis lingkungan sekolah. Wawancara digunakan untuk kebutuhan dalam mengetahui kebutuhan guru, siswa dan materi sehingga diketahui analiasis konteks yang digunakan dalam pembuatan media pembelajaran monopoli. 
Angket digunakan untuk keperluan uji validitas yang ditinjau dari aspek materi, media dan penggunaan media serta pelaksanaan pembelajaran serta digunakan dalam melakukan uji skala kecil dan besar untuk mengukur kelayakan media pembelajaran monopoli sains.

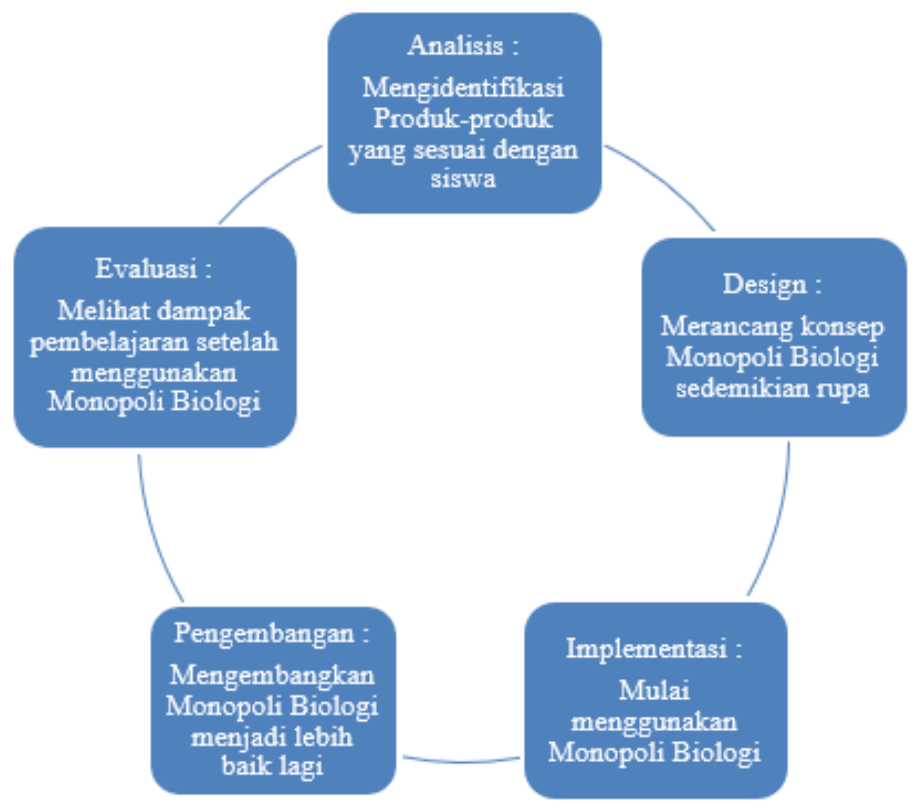

Gambar 1. Tahapan penelitian pengembangan model ADDIE (Sutarti \& Irawan, 2017)

Teknik pengumpulan data dengan menggunakan angket instrument validasi, uji kelayakan dan uji coba. Data yang diperoleh berupa data deskriptif kualitatif yang didapatkan melalui hasil review dari para validator berupa skala yang kemudian dihitung persentase dari setiap subjek yang didapatkan dari setiap validasi untuk mengetahui kelayakan prosuk yang dikembangkan. Penilaian yang digunakan menggunakan skala likert dengan skala 5. Adapun kisi instrument validasi dapat dilihat pada tabel 1.

Tabel 1. Kisi-kisi Instrument Validasi

\begin{tabular}{cll}
\hline No & \multicolumn{1}{c}{ Instrumen } & \multicolumn{1}{c}{ Aspek } \\
\hline 1 & Validasi Ahli Materi & Kualitas Isi \\
& & Keakuratan Materi dan Soal \\
& & Kemutahiran Materi dan Soal \\
& Validasi Ahli Media & Materi pembelajaran IPA \\
& & Tampilan Media \\
& & Kemenarikan Media \\
& & Kemudahan Penggunaan media \\
& Uji Kelayakan Pendidik & Daya Tarik Materi IPA \\
& & Penggunaan Media Pembelajaran MONOIN \\
& & Pelaksanaan Pembelajaran \\
& & Daya Tarik Materi IPA \\
& Penggunaan Media Pembelajaran MONOIN \\
\end{tabular}

\section{HASIL DAN PEMBAHASAN}

\section{Hasil}

Pengembangan media pembelajaran monopoli sains menggunakan model pengembangan ADDIE, dengan lima tahapan yaitu analisis, perancangan, desain, pengembangan, implementasi, dan evaluasi. Beriut langkah-langkah pengembangan pembuatan media pembelajaran monopi sains yaitu: Tahap pertama analisis (Analysis), pada tahap ini peneliti melakukan analisis kebutuhan dari guru, siswa serta materi. metode yang digunakan menggunakan penyebaran angket. Dari hasil yang didapatkan hasil bahwa pemanfaatan penggunaaan media pembelajaran belum diterapkan dalam pembelajaran IPA sehingga dalam proses belajar siswa merasa bosan dan penggunaan media oleh guru masih monoton sehingga peserta didik tidak semangat dalam proses 
pembelajaran dan penyampaian materi oleh guru belum tersampaikan dengan maksimal. Dari hasil wawancara guru dapat disimpulkan bahwa guru hanya memanfaatkan media sederhana dalam proses pembelajaran sehingga membuat siswa jenuh. Selain itu media yang digunakan biasanya hanya berupa media presentasi sederhana sehingga siswa tidak bersemangat dalam belajar karena media kurang menarik.

Tahap kedua yaitu tahap perancangan (Design) yaitu peneliti melakukan perancangan pembuatan flowchart, storyboard serta pemilihan modul cocok dengan ciri siswa, kompetesi yang dicapai strategi pembelajaran, (model serta metode), bentuk dan model asesmen serta evaluasi. Tahap ketiga yaitu pengembangan (Development), pada tahap ini peneliti mewujudkan rancangan media yang telah dirancang pada tahap sebelumnya. Pada tahap ini kegiatan yang dilakukan adalah pertama pembuatan media monopoli sains dengan tahapan perancangan, kedua membuat instrument validitas kelayakan produk yang akan dinilai oleh ahli madeia, ahli materi dan guru serta peserta didik, ketiga melakukan uji validitas oleh validator media, materi, dan guru dan keempat melakukan uji coba pada kelompok kecil dan kelompok besar untuk mengetahui kelayakan prosuk yang digunakan dalam proses pelaksanaan pembelajaran. Adapun produk media pembelajaran monopoli sains dapat dilihat pada gambar 2 sebagai berikut:
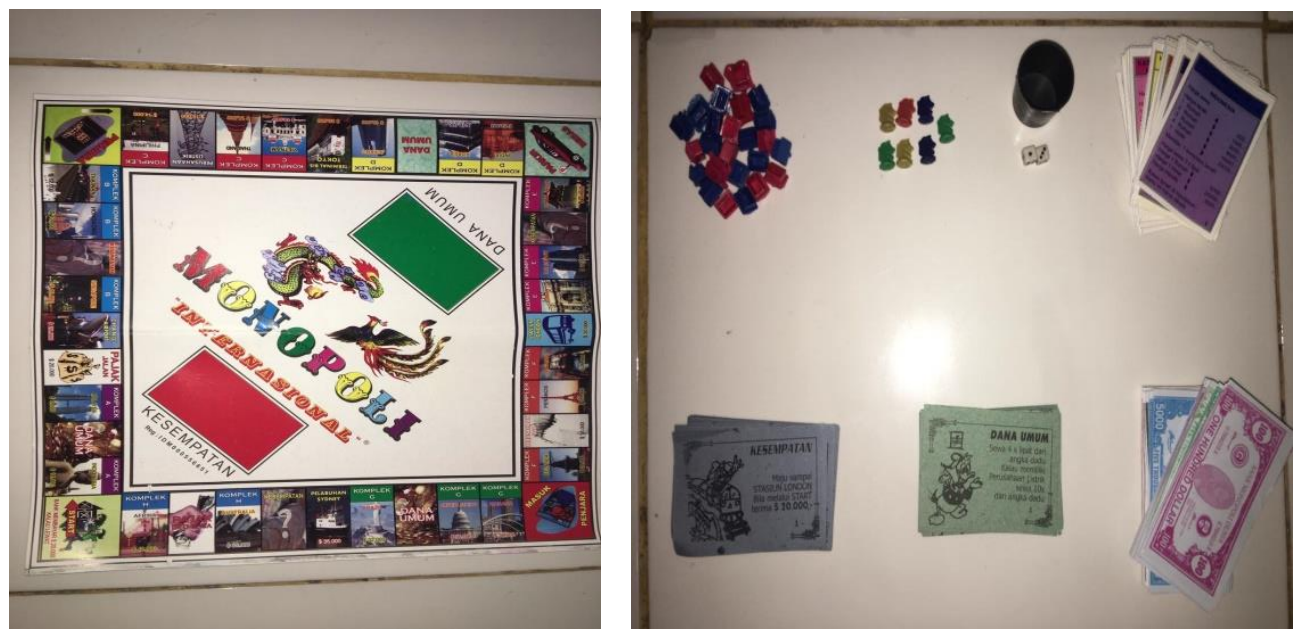

Gambar 2. Hasil Pengembangan Media Pembelajaran Monopoli Sains (MONOIN)

Tahap keempat implementasi (Implementation), pada tahap ini media monopoli sains yang telah dikembangkan dan dilakukan uji validitas oleh para ahli dan diuji coba oleh siswa kelas IV pada tahap ini juga dilakukan penyebaran angket untuk mengetahui tanggapan siswa terhadap pengembangan media pembelajaran. Hasil angket yang didapatkan adalah penggunaan media pembelajaran monopoli sains dapat menumbuhkan semangat siswa dalam proses belajar serta emmbuat peserta didik bersemangat dalam proses pembelajaran IPA. Tahap kelima yaitu tahap evaluasi (Evaluation) yaitu tahap terakhir peneliti melakukan evaluasi berdasarkan saran, kritik dan masukan dari tahap sebelumnya. Uji validasi dilakukan dengan menggunakan angket yang dilakukan ahli materi, ahli media serta uji kelayakan oleh pendidik dan uji coba oleh siswa. Berdasarkan hasil uji validasi ahli materi bahwa hasil validasi oleh ahli materi yang meliputi kualitas isi didapatkan hasil validasi sebesar 97\% dengan katgori sangat baik, selanjutnya aspek keakuratan materi dan soal didapatkan sebesar $91 \%$ dengan kategori sangat baik, aspek kemutahiran materi dan soal didapatkan sebesar 100\% dengan kategori sangat baik dan materi pembelajaran IPA didapatkan sebesar 95\% dengan kategori sangat baik. Kemudian hasil uji validitas media didapatkan hasil validasi oleh ahli media yang meliputi tampilan media MONOIN mendapatkan hasil sebesr 76\% dengan kategori sangat baik, pada aspek kemenarikan media MONOIN didapatkan hasil 85\% dengan kategori sangat baik, dan aspek kemudahan penggunaan media didapatkan hasil sebesar $80 \%$ dengan kategori sangat baik. Selanjutnya hasil vaidasi kelayakan oleh guru didapatkan hasil validasi media yang meliputi aspek daya tarik materi IPA didapatkan hasil sebesar 93\% dengan kategori sangat baik, kemudian aspek penggunaan media MONOIN didapatkan hasil sebesar 90\% dengan kategori sangat baik, dan pelaksanaan pembelajaran disapatkan hasil sebesar 93\% dengan kategori sangat baik. Hasil uji coba skala kecil oleh siswa didapat hasil uji coba skala kecil dilihat dari aspek daya tarik materi IPA didapatkan hasil sebesar 95\% dengan kategori sangat baik, kemudian aspek penggunaan media MONOIN didapatkan hasil sebesar 86\% dengan kategori sangat baik, dan pelaksanaan pembelajaran disapatkan hasil sebesar $84 \%$ dengan kategori sangat baik. Dan hasil uji coba skala besar mendapatkan hasil uji coba skala besar dilihat dari aspek daya tarik materi IPA didapatkan hasil sebesar 90\% dengan kategori sangat baik, kemudian aspek penggunaan media MONOIN didapatkan hasil sebesar 89\% dengan kategori sangat baik, dan pelaksanaan pembelajaran disapatkan hasil sebesar 84\% dengan kategori sangat baik. 
Hasil penelitian menunjukkan didapatkan hasil 94\% dengan kategori sangat baik. Validasi ahli materi yang meliputi aspek kualitas isi, aspek keakuratan materi dan soal, aspek kemutahiran materi dan soal, dan aspek pembelajaran IPA yang disajikan dalam media pembelajaran MONOIN yang dapat meningkatkan motivasi belajar siswa. Berdasarkan Ireview ahli media didapatkan hasil sebesar 79\% yang meliputi aspek tampilan media, aspek kemenarikan media, dan aspek kemudahan penggunaan. Setelah dilakukan validasi oleh ke2 ahli kemudian dilakukan uji kelayakan oleh guru mendapatkan hasil persentase sebesar 92\% dengan kategori sangat baik yang meliputi aspek daya tarik materi, aspek penggunaan media MONOIN dan pelaksanaan pembelajaran. Setelah dilakukan uji kelayakan kemudian dilakukan uji coba pada skala kecil yang didapatkan sebesar $87 \%$ dengan kategori sangat baik, dan pada skala besar didapatkan hasil sebesar 89\% dengan kategori sangat baik yang meliputi aspek daya tarik materi, aspek penggunaan media, aspek pelaksanan pembelajaran.

\section{Pembahasan}

Hasil penelitian menunjukkan bahwa diperoleh penggunan media pembelajaran MONOIN memperoleh hasil yang layak dan efektif sehingga cocok digunakan dalam pembelajaran IPA untuk kelas IV sekolah dasar. Dengan menggunakan media MONOIN menjadikan siswa bersemangat dalam proses belajar. Kegiatan pembelajaran dengan menggunakan media MONOIN menjadikan siswa mampu memahami materi yang dipelajari dan pembelajaran lebih efektif dan menarik (Aditama et al., 2019). Pada materi yang diberikan, memberikan kejelasan sesuai dengan gambar serta materi. Penyajian materi dan bahasan yang diterapkan sesuai dengan karakteristik peserta didik, sehingga membuat siswa mudah dalam memahami materi yang berisikan materi pembelajaran IPA. Ilustrasi dengan berbagai warna yang menarik sesuai dengan kontras pada gambar tentu memberikan ketertarikan siswa dalam mempelajari materi IPA dan mampu membuat siswa senang (Mawanto et al., 2020). Media MONOIN dipilih sebagai media pembelajaran yang tidak terlepas dari karakteristik dari media monopoli sendiri dimana media tersebut terdiri dari gambar-gambar dan materi yang di berikan namun tetap memberikan makna yang banyak. Dengan media yang menarik akan mampu menigkatkan motivasi belajar siswa, yang mana motivasi belajar siswa merupakan salah satu faktor yang meningkatkan minat belajar, yang menjadi suatu pendorong yang membuat seseorang ingin belajar. Motivasi belajar ialah dorongan internal dan eksternal pada siswa yang sedang belajar untuk mengadakan perubahan tingkah laku (Putri Ningrat et al., 2018). Dengan adanya motivasi belajar akan meningkatkan hasil belajar siswa. Media pembelajaran MONOIN dikembangkan untuk membantu guru dalam proses pembelajaran IPA serta memotivasi semangat belajar siswa dan memberikan pengalaman belajar siswa.

Penelitian ini sejalan dengan hasil penelitian sebelumnya yang telah dilakukan menyatakan bahwa media pembelajaran Monopoli dapat menumbuhkan kemampuan pemahaman konsep IPA dan dapat meningkatkan semangat dalam belajar (Ulfaeni, 2018; Risma et al., 2019). Penggunaan media pembelajaran monopoli juga menunjukan bahwa dapat menumbuhkan kemampuan pemahaman konsep IPA dan membantu khususnya siswa untuk memahami pengetahuan IPA dalam memecahkan masalah dan penerapan dalam kehidupan sehari-hari (Ulfaeni, 2018; Arshad et al., 2021). Kemudian media pembelajaran monopoli mampu meningkatkan semangat belajar peserta didik dan dapat membantu dalam pemahaman materi pada peserta didik dengan hasil menunjukkan bahwa pengembangan media monopoli dapat meningkatkan kemampuan pemahaman konsep IPA peserta didik serta meningkatkan motivasi siswa (Risma et al., 2019). Jadi hasil penilitian ini menunjukkan bahwa media pembelajaran MONOIN layak digunakan sebagai media pendidikan IPA di semester I pada kelas IV sekolah dasar yang mana dapat meningkatkan motivasi serta hasil belajar siswa selain itu siswa juga mampu memahami materi dengan mudah. Selaras dengan hal tesebut dapat dibuktikan dengan kelebihan yang dilakukan pada penelitian ini. Kelebihan pada penelitian ini ialah mudah digunakan dalam pembelajaran serta dapat digunakan dalam pembelajaran selama satu semester untuk muatan IPA. Namun, penelitian ini memiliki kelemahan yaitu media yang digunakan hanya dapat digunakan secara langsung dalam proses belajar. Implikasi dalam penelitian ini adalah media pembelajaran MONOIN dapat dikembangkan untuk materi lainnya dan dapat dikembangkan untuk muatan pelajran lainnya yang sesuai kontes karakteristik siswa sehingga proses pembelajaran efektif dan efisien (Diella \& Ardiansyah, 2019). Selanjutnya implikasi lain dalam penelitian ini ialah dapat digunakan oleh guru sebagai salah satu inovasi terbaru dalam penggunaan media pembelajaran IPA yang lebih menyenangkan dan memberikan pengalaman.

\section{SIMPULAN}

Berdasarkan penelitian yang telah dilakukan, diperoleh simpulan bahwa media pembelajaran MONOIN pada pembelajaran IPA memenuhi kriteria kelayakan sehingga media pembelajaran yang dihasilkan dapat membantu siswa belajar memahami materi muatan IPA dan siswa lebih bersemangat dalam prose pembelajaran. Rekomendasi untuk penelitian selanjutnya yaitu perlu adanya pengembangan media pembelajaran MONOIN lainnya yang lebih menarik dan lebih bervariatif lagi. 


\section{DAFTAR PUSTAKA}

Aditama, H. S., Zainuddin, M., \& Bintartik, L. (2019). Pengembangan LKPD Berbasis HOTS pada Pembelajaran Matematika Materi Volume Bangun Ruang Kelas V SDN Sentul 1. Wahana Sekolah Dasar; Vol 27, No 2 (2019), 27(2), 29-35. http://journal2.um.ac.id/index.php/wsd/article/view/12471.

Ardhani, A. D., Ilhamdi, M. L., \& Istiningsih, S. (2021). Pengembangan Media Pembelajaran Berbasis Permainan Monopoli pada Pelajaran IPA. Jurnal Pijar Mipa, 16(2), 170. https://doi.org/10.29303/jpm.v16i2.2446.

Arshad, A. M., Halim, L., \& Nasri, N. M. (2021). Impact of Integrating Science and Engineering Teaching Appoarch on Student' Achievement: A Meta Analysis. 10(2), 159-170. https://doi.org/10.15294/jpii.v10i2.29839.

Asyhari, A., \& Silvia, H. (2016). Pengembangan Media Pembelajaran Berupa Buletin dalam Bentuk Buku Saku untuk Pembelajran IPA Terpadu. Jurnal Ilmiah Pendidikan Fisika Al-Biruni, 5(1), 1-13. https://doi.org/10.24042/jpifalbiruni.v5i1.100.

Deviana, D. R., \& Prihatnani, E. (2018). Pengembangan Media Monopoli Matematika pada Materi Peluang untuk Siswa SMP. Jurnal Review Pembelajaran Matematika, 3(2), 114-131. https://doi.org/10.15642/jrpm.2018.3.2.114-131.

Diella, D., \& Ardiansyah, R. (2019). Pelatihan Pengembangan LKPD berbasis Keterampilan Proses Sains Dan Instrumen Asesmen KPS Bagi Guru IPA. Publikasi Pendidikan, 9(1), 7. https://doi.org/10.26858/publikan.v9i1.6855.

Ega Rima Wati, S. pd. (2016). Ragam Media Pembelajaran (A. Jarot (ed.)). Kata Pena.

Fitriyati, I., Hidayat, A., \& Munzil. (2017). Pengembangan Perangkat Pembelajaran IPA untuk Meningkatkan Kemampuan Berpikir Tingkat Tinggi dan Penalaran Ilmiah Siswa Sekolah Menengah Pertama. Jurnal Pembelajaran Sains, 1(1), 27-34. http://dx.doi.org/10.17977/um033v1i1p27-34.

Gumilang, juwita retna. (2019). Pengaruh Penggunaan Media Pembelajaran Monopoli Terhadap Hasil Belajar Ipa Siswa Kelas Iii Sd Negeri 1 Gondang. EDUPROXIMA: Jurnal Ilmiah Pendidikan IPA, 1(2). https://doi.org/10.29100/eduproxima.v1i2.1112.

Hakim, L. (2018). Pengembangan Media Pembelajaran Pai Berbasis Augmented Reality. Lentera Pendidikan: Jurnal Ilmu Tarbiyah Dan Keguruan, 21(1), 59-72. https://doi.org/10.24252/lp.2018v21n1i6.

Haviz, M. (2016). Research and Development; Penelitian Di Bidang Kependidikan Yang Inovatif, Produktif Dan Bermakna. Ta'dib, 16(1). https://doi.org/10.31958/jt.v16i1.235.

Hidayah, P., Untari, M. F. A., \& Wardana, M. Y. S. (2018). Pengembangan Media Sepeda (Sistem Peredaran Darah) dalam Pembelajaran IPA di Sekolah Dasar. International Journal of Elementary Education, 2(4), 306. https://doi.org/10.23887/ijee.v2i4.16109.

Kurniawan, D. A. (2020). Penggunaan Media Belajar Monopoli Untuk Meningkatkan Motivasi dan Hasil Belajar Siswa. Jurnal Review Pendidikan Dan Pengajaran, 3, 10-15. https://doi.org/10.31004/jrpp.v3i1.720.

Kusumaningrum, D. (2018). Literasi Lingkungan Dalam Kurikulum 2013 Dan Pembelajaran Ipa Di Sd. Indonesian Journal of Natural Science Education (IJNSE), 1(2), 57-64. https://doi.org/10.31002/nse.v1i2.255.

M.Ramli. (2017). Media Pembelajaran Dalam Perspektif Al Quran dan Hadist. 13(23), 130-154. http://dx.doi.org/10.18592/ittihad.v13i23.1737.

Masturah, E. D., Mahadewi, L. P. P., \& ... (2018). Pengembangan Media Pembelajaran Pop-Up Book pada Mata Pelajaran IPA Kelas III Sekolah Dasar. Jurnal EDUTECH ..., 6, 212-221. http://dx.doi.org/10.23887/jjpgsd.v9i3.37973.

Mawanto, A., Siswono, T. Y. E., \& Lukito, A. (2020). Pengembangan Media Cerita Bergambar untuk Melatih Kemampuan Berpikir Kreatif Siswa pada Materi Pecahan Kelas II. Jurnal Cendekia: Jurnal Pendidikan Matematika, 4(1), 424-437. https://doi.org/10.31004/cendekia.v4i1.243.

Monita, F. A., \& Ikhsan, J. (2020). Development Virtual Reality IPA (VR-IPA) learning media for science learning. Journal of Physics: Conference Series, 1440(1). https://doi.org/10.1088/1742-6596/1440/1/012103.

Mukti, intan nur cahya, \& Nurcahyo, H. (2017). Developing Computer- Based Biology Learning Media to Improve the Students' Learning Outcom. Jurnal Inovasi Pendidikan IPA, 3(2), 137-149. https://doi.org/10.21831/jipi.v3i2.7644.

Nomleni, F. T., \& Manu, T. S. N. (2018). Pengembangan Media Audio Visual dan Alat Peraga dalam Meningkatkan Pemahaman Konsep dan Pemecahan Masalah. Scholaria: Jurnal Pendidikan Dan Kebudayaan, 8(3), 219230. https://doi.org/10.24246/j.js.2018.v8.i3.p219-230.

Nurlaela, L. (2017). Pengaruh Media Pembelajaran Dan Motivasi Belajar Terhadap Kemampuan Berpikir Kritis Siswa. Jurnal Ilmiah Pendidikan Guru Sekolah Dasar, 1(2), 180-187. https://doi.org/https://doi.org/10.31326/jipgsd.v1i02.108.

Priansa, D. J. (2017). Pengembangan Strategi \& Model Pembelajaran Inovatif, Kreatif, Dan Prestatif Dalam Memahami Peserta Didik (Tim Redaksi Pustaka setia (ed.); Cetakan Ke). CV Pustaka Setia.

Putri Ningrat, S., Tegeh, I. M., \& Sumantri, M. (2018). Kontribusi Gaya Belajar Dan Motivasi Belajar Terhadap Hasil Belajar Bahasa Indonesia. Jurnal Ilmiah Sekolah Dasar, 2(3), 257. https://doi.org/10.23887/jisd.v2i3.16140.

Rahman, A. Z., Hidayat, T. N., \& Yanuttama, I. (2017). Media Pembelajaran IPA Kelas 3 Sekolah Dasar 
Menggunakan Teknologi Augmented Reality Berbasis Android. Seminar Nasional Teknologi Informasi Dan Multimedia, $\quad 5(1), \quad 4-6-43$. https://ojs.amikom.ac.id/index.php/semnasteknomedia/article/view/1797.

Risma, R., Bua, A. T., \& Annisa, M. (2019). Pengembangan Media Pembelajaran Monopoli pada Tema Ekosistem untuk Siswa Sekolah Dasar. Jurnal Komunikasi Pendidikan, 3(2), 92. https://doi.org/10.32585/jkp.v3i2.301.

Siskawati maya, pargiti, P. (2016). Pengembangan Media Pembelajaran Monopoli Untuk Meningkatkan Minat $\begin{array}{llll}\text { Belajar } & \text { Geografi } & \text { Siswa. } & \text { 7(1), }\end{array}$ http://jurnal.fkip.unila.ac.id/index.php/JSS/article/view/11522/8189.

Suryani, E. (2016). Analisis Pemahaman Konsep Ipa Siswa Sd Menggunakan Two-Tier Test Melalui Pembelajaran Konflik Kognitif. Journal of Primary Education, 5(1), 56-65. https: //doi.org/10.15294/JPE.V5I1.12893.

Sutarti, T., \& Irawan, E. (2017). Kiat Sukses Meraih Hibah Penelitian Pengembangan (Mulyadi (ed.); 1st ed.). DEEPUBLISH (Grup Penerbitan CV Budi Utama).

Ulfaeni, S. (2018). Pengembangan Media Monergi (Monopoli Energi) Untuk Menumbuhkan Kemampuan Pemahaman Konsep Ipa Siswa Kelas Iii Sdn Pedurungan Kidul 02 Semarang. Profesi Pendidikan Dasar, 1(2), 143. https://doi.org/10.23917/ppd.v1i2.4990.

Wahyuni, S., Erman, Sudikan, S. Y., \& Jatmiko, B. (2020). Edmodo-based Interactive Teaching Materials as an Alternative Media For Science Learning to Improve Critical Thinking Skills of Junior High School Students. International Journal of Interactive Mobile Technologies, 14(9), 166-181. https://doi.org/10.3991/ijim.v14i09.13041.

Wahyuningtyas, R., \& Sulasmono, B. S. (2020). Pentingnya Media dalam Pembelajaran Guna Meningkatkan Hasil Belajar di Sekolah Dasar. Edukatif: Jurnal Ilmu Pendidikan, 2(1), 23-27. https://doi.org/10.31004/edukatif.v2i1.77.

Wardhana, ludfi A., \& Alawiyah, yustika tuti. (2017). Pengembangan Media Pembelajaran Monopoli Berbasis tematik pada Tema 4 (Hidup Bersih dan Sehat) Kelas II SDN Sumbersuko Kabupaten Probolinggo. $\begin{array}{llll}\text { Kreano, Jurnal } & \text { Matematika } & \text { Kreatif-Inovatif, } & \text { 8(2), }\end{array}$ https://doi.org/10.15294/kreano.v8i2.10014.

Wicaksono, A. G., Jumanto, \& Irmade, O. (2020). Pengembangan Media Komik Komsa Materi Rangka pada Pembelajaran IPA di Sekolah Dasar. PE:Jurnal Pendidikan Dasar Dan Pembelajaran, 10(2), 215-226. https://doi.org/10.25273/pe.v10i2.6384.

Wijaya, E. Y., Sudjimat, D. A., \& Nyoto, A. (2016). Transformasi Pendidikan Abad 21 Sebagai Tuntutan. Jurnal Pendidikan, 1, 263-278. https://scholar.google.co.id/citations?user=l2KFhksAAAAJ\&hl=id.

Wulandari, R., Susilo, H., \& Kuswandi, D. (2016). Multimedia Interaktif Bermuatan Game Edukasi Sebagai Salah Satu Alternatif Pembelajaran Ipa Di Sekolah Dasar. Jurnal Pendidikan, 1-8. http://dx.doi.org/10.17977/jptpp.v2i8.9759.

Zaenal Fais, M., Listyarini, I., \& Nashir Tsalatsa, A. (2019). Pengembangan Media Papin dan Koja (Papan Pintar dan Kotak Ajaib) Sebagai Media Pembelajaran Matematika. Jurnal Penelitian Dan Pengembangan Pendidikan, 3(1), 26. https://doi.org/10.23887/jppp.v3i1.17097.

Zulirfan, Z., Rahmad, M., Yennita, Y., Kurnia, N., \& Hadi, M. S. (2018). Science Process Skills and Attitudes toward Science of Lower Secondary Students of Merbau Island: A Preliminary Study on the Development of MaritimeBased Contextual Science Learning Media. Journal of Educational Sciences, 2(2), 90. https://doi.org/10.31258/jes.2.2.p.90-99. 